https://doi.org/10.18485/iipe_cpti.2020.ch4

\title{
NACIONALNA DRŽAVA: SMISAO I PERSPEKTIVE
}

\author{
Vladimir N. CVETKOVIĆ
}

\author{
„Predskazivanje budućnosti svoj \\ izvor ima samo u sagledavanju prošlosti“ \\ H. G. Gadamer
}

\begin{abstract}
Apstrakt: U prvom delu rada autor raspravlja o osnovama i evoluciji legitimacijskih načela kojima se opravdava delatnost i svrha moderne države. Pored toga, $u$ radu se daje pregled mogućih političkih formi i strukturnih odnosa pomoću kojih je nastojalo da se dođe do uspešne (efikasne) i legitimne (prihvaćene) vlasti, odnosno društvenog i političkog poretka koji funkcionišu u skladu sa proklamovanim načelima. U središnjem delu rada autor prikazuje postepeni nastanak moderne (nacionalne) države i kritički sagledava pojedine teze iz korpusa političke filozofije, koje su služile kao opravdanje za stvaranje modernih država. Prema mišljenju autora, moderna država je postala korporacija koja upravlja drugim korporacijama, kao i amalgam društvenih veza i odgovornosti usmeravan od strane legitimnih (ovlašćenih) posvetovljenih vođa. Takođe, po njegovom mišljenju, u pokušajima da legitimiše nove forme vladanja, država je naizmenično igrala ulogu „,noćnog čuvara” (minimalistički liberalni koncept), ili pak "Velikog brata” (maksimalistički totalitarni koncept), bila je i ,,socijalni inženjer" (komunizam) i ",svetovno božanstvo" (fašizam/nacizam), vrednosno neutralni ",regulator slobodnog tržišta" (liberalizam) i vrednosno zainteresovani "distributer bogatstva" (socijal-demokratija). Iako je u hladnoratovskom nadmetanju pobedila liberalna ideologija, ,sistemska kriza" koja je od samog početka činila privredno i političko jezgro liberalizma (i/ili modernog sveta), nije iščezla zajedno sa svojim neprijateljem (sovjetskim modelom), pa se, po mišljenju autora, ne može govoriti o kraju istorije, dok se budući svetski duhovni i politički tokovi ne mogu sa sigurnošću predviđati, već samo naslućivati.

Ključne reči: legitimitet, država, ideologija, politička filozofija, istorija.
\end{abstract}

\footnotetext{
${ }^{1}$ Autor je redovni profesor i dekan na Fakultetu bezbednosti, Beograd, e-mail: vcvetkovic@fb.bg.ac.rs.
} 


\section{Uvod}

Na koji način i uz koja načela uspostaviti i održati unutrašnje jedinstvo potrebno da se postigne sigurnost i poveća moć političke zajednice? To su bila i ostala dva osnovna pitanja i zadatka tokom svekolike istorije politike. U modernom diskurzivnom ključu ona se oblikuju kroz pojmove pravde, suvereniteta i bezbednosti, pri čemu svaki od njih ima svoju unutrašnju i spoljašnju dimenziju, tj. značenje i upotrebu. Pravda je nužan uslov društvene solidarnosti i osnovna pretpostavka dugoročne održivosti unutrašnjeg poretka. Isto važi i za uspostavljanje i održavanje političkog suvereniteta (nezavisnosti), kao glavne brane spoljašnjim, po pravilu negativnim uticajima. Zajedno, pravda i suverenitet obezbeđuju uređen i stabilan politički poredak koji je ujedno pretpostavka i posledica bezbednosti političke zajednice. U tom pojmovnom trouglu i iskustvenom ambijentu nastaje i traje nacionalna država - glavni politički proizvod modernosti. $^{2}$

Međutim, nezavisno od brojnih kontroverzi oko značenja i domašaja pravde, suvereniteta i bezbednosti nacije i/ili države, izvesno je da u datom hermeneutičkom kontekstu, kao i uvek, sve zavisi od legitimiteta. Čime se opravdava postojanje države? Da li time što poseduje monopol nad upotrebom sile? Možda zato što je ",agent” društvene i lične bezbednosti, čuvar imovine i pouzdani poslodavac? Država svakako može da bude i više ili „uzvišenije” od svojih funkcionalnih uloga (idol, svetinja, smisao, ponos za svoje građane/državljane), kao i mnogo manje, a fatalnije: gospodarnasilnik, nemilosrdni upravitelj, hladnokrvni dželat... Mada se na prvi pogled čini da je ovde, kao i uvek u ljudskim poslovima, "sve moguće”, te da je "svaki razlog - dobar razlog", pogotovo ako se može potkrepiti argumentima prinude, ponuda autentičnih, ne i izvedenih (posrednih ili čisto utilitarnih) legitimacijskih političkih načela, zapravo i nije naročito velika: desetak, ne više! Pojavljuju se praktično u svim vrstama političkih zajednica, ali nemaju svuda i uvek isto značenje i "težinu”.

Predmoderna istorija iznedrila je nekoliko legitimacijskih načela koje navodimo po rangu upotrebljivosti, odnosno korisnosti: moć, slava,

\footnotetext{
${ }^{2}$ Otuda ne iznenađuje što se u modernoj političkoj teoriji i praksi gotovo po pravilu izjednačavaju državna suverenost i nacionalna bezbednost. Vidi: Vladimir N. Cvetković, "Državna suverenost i/ili nacionalna bezbednost”, u: Državni poredak Suverenitet u vremenu globalizacije, SANU, Beograd, 2019.
} 
identitet, mir i pravda. To su najstarija i ujedno univerzalna legitimacijska načela, nasleđena od klasičnih političkih zajednica (kraljevstva, carstva, polisi, patesijati i dr.). Uz određene modalitete i politička akcentovanja ona važe i danas. Zato se u već odgovarajuće prepakovanim varijantama nalaze $\mathrm{u}$ svim modernim ideološkim programima i političkim parolama, uključujući tu i ustave ili statute nacionalnih država. Navedenoj rukovodećoj sumi političkih ciljeva i/ili razloga opravdanja vlasti, modernost je u svom herojskom dobu (XVIII-XIX vek) pridodala pojmove slobode i jednakosti koji se nalaze u disjunktivnim i alternativnim vezama sa politikom i ekonomijom. Tako se $u$ ideološkim talasima i političkim modama potiru ili izjednačavaju ekonomske i političke slobode, sukobljavaju ili međusobno podržavaju politička i ekonomska jednakost itd. Neobično je što uz njih parazitira i za politiku neobičan zahtev-načelo koji se odnosi na ostvarivanje individualne, odnosno kolektivne sreće! ${ }^{3}$

Komplotu datih legitimacijskih načela kojima se opravdava delatnost $\mathrm{i}$ svrha moderne (nacionalne) države, savremenost je pridodala još dva, podjednako kontroverzna pojma-načela: suverenitet i demokratiju. Oni se istovremeno vezuju za državu (kao oblik i organizaciju vlasti), kao i za njen politički izvor i utoku -,,narod", koji je u moderni transcendirao u svoj „viši” oblik - naciju (kao sredstvo i smisao identiteta). Tu se faktički iscrpljuje lista političko-etičkih ciljeva i/ili teorijsko-ideoloških načela pomoću kojih se opravdava postojanje države. Delokrug ovlašćenja i delotvornosti takve (moderne = nacionalne; desakralizovane i depersonalizovane) države, vremenom se proširio do neviđenih i neslućenih političkih, ekonomskih i kulturnih granica, uz sve kontroverze koju takva uloga i moć sobom nose.

\section{Teorijske kontroverze}

Relativno limitirani broj ideoloških ciljeva i/ili legitimacijskih političkih načela ne ograničava i izbor načina da se oni dosegnu. Gotovo svi najvažniji društveni i politički problemi, da ne kažemo „bezbednosni izazovi” sa

\footnotetext{
${ }^{3} \mathrm{U}$ ključnom programskom dokumentu modernog liberalizma - Deklaracija o nezavisnosti (britanskih kolonija u Severnoj Americi, 1776), pojam sreće se pojavljuje uz „narodnu sigurnost” koju obezbeđuje vlada zasnovana na „saglasnosti onih nad kojima se vlada". Pravo na sreću se vezuje uz druga dva neotuđiva prava - život i slobodu - koje je Bog dodelio ljudima koji su stvoreni, tj. rođeni međusobno jednaki. Priroda te jednakosti (p)ostaće glavni kamen spoticanja u modernoj političkoj eri.
} 
kojima se suočavaju političke zajednice, svode se u krajnjem slučaju na pronalaženje adekvatnog načina/sredstva da se institucionalizaciju legitimacijska načela. Štaviše, delotovornost institucija je često preča od „ispravnosti” ideja koje obrazuju legitimacijske principe/načela. U iskušenju smo da zaključimo, posle navođenja svih (ne)ubedljivih razloga za opravdanje vlasti, kako se sve što je „praktičko” svodi na organizaciju institucionalnog okvira unutar koga funkcionišu odnosi između onih koji vode (subjekti moći) i onih koji su vođeni (predmeti moći).

Istorija poznaje više političkih recepata po tom pitanju: (a) vladavina najjačih ratnika i/ili vladavina mudrih i pravednih vladara (koji mogu ali i ne moraju biti vođe-ratnici); (b) vladavina svetih ljudi u likovima verskih vođa (gnevnih pravednika, gordih mučenika i sl.), ili za ovozemaljske stvari nezainteresovanih svetaca (Platonovi filozofi, hrišćanski isposnici, budistički sveštenici i sl.); (v) vladavina oligarhijske manjine (koju čine plemeniti aristokrati ili bogati oligarsi - ili svi oni zajedno), ili vladavina demokratske većine (koju čini masa vođena emocijama i demagozima); (g) vladavina stručnjaka (koji su, obično po vlastitom sudu, školovani i profesionalno osposobljeni za "upravljanje sistemima”) ili pak (d) predstavnička vladavina (u kojoj svaka društvena grupa štiti svoje interese preko izabranih posrednika) itd. To su tek neke od mogućih političkih formi i strukturnih odnosa pomoću kojih se nastojalo i nastoji doći do uspešne (efikasne) i legitimne (prihvaćene) vlasti, odnosno društvenog i političkog poretka koji funkcionišu u skladu sa proklamovanim načelima.

Međutim, uprkos prividnom postojanju beskrajnih mogućnosti za modeliranje odnosa između vođa i vođenih, tj. elita koje donose i sprovode odluke s jedne, i drugih tj. preostale „mase”, ,narodne baze” ili „izbornog tela" koji trpe posledice donesenih odluka s druge strane, čini se da su i ovom aspektu konkretne politike realne mogućnosti ograničene. Tako su bar mislili antički mislioci: Platon, a pre njega i Herodot, pokazali su da se političke formacije i/ili oblici vlasti svagda vrte $\mathrm{u}$ zatvorenom istorijskom krugu naizmeničnog smenjivanja režima aristokratije, oligarhije, demokratije i tiranije. Njihovim nalazima Aristotel i potonji filozofi nisu imali šta bitno novo i drugačije da dodaju. U datom vidokrugu, "istorija” politike, tj. političkih formi, nalikuje na "večno isto" kretanje planeta u kosmosu: ciklično ponavljanje istih putanja i ishodišta. Slično razumevanje politike i istorije imali su i drugi ondašnji civilizacijski krugovi na Bliskom i Dalekom istoku: od Vavilona i Egipta, do Indije i Kine, svuda je reč o 
cikličnom poimanju politike i istorije. Neočekivana promena je došla sa novom monoteističkom verom nastalom na starom Bliskom istoku.

Hrišćanski teolozi su, posle dugo iskazivane ravnodušnosti spram istorije i njenih političkih formi, ciklično kruženje zamenili transcendentnim čudom, intervencijom transcendentalnog bića u vremenu: Bog je stvorio svet i vreme u njemu, vanvremenski raj i sve što je savršeno, da bi potom sišao među "pale”, tj. grešne ljude koji su ga iznevereli i čak sebe žrtvovao radi njihovog ponovnog oboženja, tj. povratka u rajsko okrilje. Istorija ljudskog (kao političkog) postojanja dobila je tako svoj smisao, štaviše (konačan) cilj. Bog, odnosno Sveti duh, kao njegova emanacija u istoriji, prepoznaje ili unosi svrhu u (činilo se) beskrajne ljudske borbe oko vlasti i moći. Tako je, pomalo neočekivano, ideja o božijem prisustvu na zemlji i njegovoj dobrovoljnoj žrtvi za spasenje čovečanstva, posredno promovisala narativ o evoluciji $u$ istoriji, odnosno o postojanom napretku koji vodi ka eshatološkom cilju. ${ }^{4}$

Preokret date refleksije došao je sa modernom, tj. desakralizovanim svetom politike, privrede i kulture u kome su novi, samoimenovani "prosvetitelji" (književnici i deo političke elite tradicionalnog staleškog društva) i njihovi manje pompezni ali zato mnogo uticajniji savremenici (poslovna i delimično vojna elita), istoriju počeli da tumače kao čisto ljudsku delatnost, a politiku kao proizvod sukoba volja i interesa u potrazi za „kompromisom" ili konačnom pobedom. Tako je onaj „večno isti" istorijski krug moći, koga su na praktičkom nivou "otkrili” grčki filozofi, a u religijskoj dimenziji „,prevazišli” hrišćanski teolozi, naizgled iščezao, a da bi na njegovo mesto stupala politička teorija kao "moralna nauka”, ubrzo potom i kao otvoreno „politička nauka”, odnosno scijentističko „uputstvo za upotrebu" znanja i vlasti. Centralna kategorija oko koje se pri tome sve vrtelo bila je (i ostala) nova, moderna vrsta političke zajednice - država.

\footnotetext{
${ }^{4} \mathrm{U}$ prvom (filozofskom) pristupu politika je teorijski važna, ali iskustveno limitirana priča večnog vraćanja istih ili sličnih formi vladavine, dok su u drugom (teološkom) viđenju stvari, možda baš zbog prethodnog filozofskog zaključka, politika i oblici vlasti prebačeni na nivo božanskih planova koji imaju transcedentni smisao učitan u iskustveni svet istorije.Više o tome: vidi analize Platonove i Avgustinove političke filozofije, na koje se nadovezuju refleksije o modernim filozofskim učincima po tom pitanju do kojih su došli Dekart, Kant i Hegel - Vladimir N. Cvetković: „Filozofsko sabiranje epohe“, u: Moć i mudrost (O političkoj dimenziji filozofije), Službeni list SRJ, Beograd 2001.
} 
Moderna država je nastajala postupno, zajedno sa širenjem svetskog privredno-političkog sistema. Potreba za centralizovanom vlašću, predvidljivim, dakle zakonitim, delotovornim i dugoročnim upravljanjem, zajedno sa razvojem kapitalizma, učinili su da se srednjovekovna dinastička uprava $u$ najvećim evropskim zemljama pretoči najpre $u$,,apsolutističke monarhije", a odmah potom i nacionalne države sa depersonalnim sistemom vlasti. Tako je u XIX veku formiran političko-privredni ambijent pogodan za uspostavljanje nacionalnih država na globalnom nivou, tj. na doslovno svakom kutku Zemljine površine. Utoliko se sve današnje države zasnivaju se na manje-više istim ili sličnim ekonomskim osnovama i razvijaju političke institucije koje zahtevaju iste ili slične legitimacijske osnove.

Onda kada je, uz puno slučajnosti i nepredvidljivih okolnosti, konačno konstituisana moderna (nacionalna) država, politika i sve u vezi sa njom prešlo je u domen "naroda” i novostvorenih "nacija”. Time je politika po prvi put $\mathrm{u}$ istoriji dospela u ruke svetovnih vođa - "političara”, tj. profesionalnih političkih zanatlija ili ,stručnjaka za politiku”. Moderne posvetovljene vođe se razlikuju u odnosu na svoje predmoderne divinizovane pandane (knezove, kraljeve, careve i druge vladare) utoliko što vlastitu moć mogu i moraju da grade više na snazi organizacije i njenih unutrašnjih pravila, a manje ili nikako na osnovu lične harizme, "poziva sudbine”, "plemenitog porekla” ili "božanskog nadahnuća”. Razlog tome jesu promenjene osnove legitimnosti zajedničkog života (politička zajednica i njeno dobro više nisu po definiciji iznad pojedinca, naprotiv), baš kao i promenjeni način organizacije privrednog i duhovnog bivstvovanja (kapitalizam je postao model funkcionisanja svih aspekata društva, a "sekularizacija“, odnosno posvetovljenje, univerzalni model mišljenja i delovanja). ${ }^{5}$

Istovremeno, političku filozofiju i teologiju nadomestila je moderna (društvena) nauka i scijentistička vera u moć političke (pred)vidljivosti pomoću (pro)računa, objektivnih indikatora i (ne)zavisnih varijabli. Metodološki ideal moderne nauke - matematičko modelovanje iskustvenog

\footnotetext{
${ }^{5}$ Rečena sekularizacija, kao preobražaj svetog u svetovno, nije niti može biti prosto „preokretanje” starog ili možda konačno sticanje „prvobitnosti“ , već je zapravo "padanje“" u novo u kome nema nikakve „supstancije”, tj. čvrstog (transcendentnog) oslonca iz koga sve niče po određenom logičkom redu ili smislu. Više o tome: vidi Hans Blumenberg, Legitimnost novog veka, Izdavačka kljižarnica Zorana Stojanovića, Sremski Karlovci - Novi Sad 2004. Iz drugog ugla isto - Vladimir N. Cvetković, Volja za novo (O genealogiji modernosti), Dereta, Beograd 2007.
} 
istraživanja prirode uz postupno osvajanje ili ovladavanje njenim "zakonitostima", preneo se u svet politike i potonjih "društvenih" i "duhovnih" nauka koje, navodno, po istom modelu, mogu i treba da zagospodare istorijom i/ili društvom.

Legitimitet je u tom slučaju, kao i svaki drugi „predmet istraživanja”, postao merljiva vrednost, političko dobro koje se može „izračunavati” i kao takvo upotrebljavati. Njegova društvena, politička i ekonomska cena mogu se ukalkulisati u celokupni politički paket, ti. ideološki pogon koji po potrebi povećava ili smanjuje, onako kako već nalažu prilike na tržištu moći. Upravo tome i služe sve one brojne ankete i ispitivanja javnog mnjenja preko kojih se prave rang liste i indeksi apstraktnih političkih stanja i očekivanja. Tako se dolazi do često besmislenih merenja „indeksa slobode” ili „indeksa sreće", koji kompromituju nešto smislenije ali isto tako neuhvatljive topliste demokratije ili korupcije. Politički legitimitet, kao i sve druge vrednosti $\mathrm{u}$ datom kontekstu, (p)ostaje tek neka vrsta „političke robe" koja se kupuje i prodaje na tržištu ideja i interesa, pri čemu "cena" varira u zavisnosti već od aktuelne ponude i potražnje države.

Sve što je rečeno ne predstavlja karikaturalan opis političke savremenosti, niti je lamentiranje nad modernošću. Još uvek smo na nivou puke deskripcije onoga što je na delu i što se pred našim očima ubrzano razvija u nejasnom pravcu. Pravo pitanje je da li moderna merkantilizacija i scijentizacija politike znači da je sa „izvornim” političkim legitimitetom gotovo? Da li se politika, kao mišljenje i delovanje, konačno utopila u kalkulativnom ,jednodimenzionalnom umu" koji postepeno odustaje čak i od privida pluralnosti i slobode? Da li će svaka borba za i oko političkih vrednosti i njihove institucionalizacije (i) ubuduće o(p)stajati samo u kontekstu modernog gospodarenja prirodom i društvom? Drugim rečima, da li su klasična legitimacijska načela danas naprosto „prevaziđena” u svetu "naučnog praznoverja” i uz tiransku vladavinu javnosti koja stalno očekuje novi i savršeniji - „srećniji svet”, koji je utemeljen na tehnološkom napretku i menadžerskim mantrama? Da li će se održati trend redukcije političke delatnosti na "adekvatno", dakle „naučno utemeljeno" organizovanje društva, tj. na tehničke inovacije pomoću kojih se oblikuju očekivanja i emocije jednih, a zadovoljavaju interesi i potrebe drugih aktera u političkoj areni? Da li sve to znači da politika kao „umetnost mogućeg” zapravo više i ne postoji? Sve navedene nedoumice vode ka istom sudbonosnom pitanju: koja je sudbina države? 
Doslovno do juče su se postavljala otrcana retorička pitanja „o kraju” istorije, epohe ili države, da bi se danas, $u$ vremenu pandemija i pankriza, interes saznanja okrenuo $u$ drugom pravcu, manje optimističnom a više fatalističkom, i čak konspirativnom. Ono što, međutim, ne prestaje da provocira političko i svako drugo diskurzivno mišljenje o društvu jeste pitanje - da li se politika i njena legitimacija i dalje odvijaju u domenu nacionalne države? Da li druge dimenzije političkog (međunarodna, regionalna, klasna, rasna, ekološka ili neka druga politika) otpremaju nacionalnu državu u prošlost? Postavljeno sa manje retoričke strasti, glavno teorijsko i praktično pitanje savremenosti glasi: da li postupni ali očigledni nadolazak „,svetske civilizacije" označava potiranje tradicionalnih regionalnih kultura i zajedno sa njima nestanak modernih (nacionalnih) država?

Potvrdan odgovor na datu upitanost prevladavao je na katedrama političkih nauka prestižnih univerziteta i čak dominirao realpolitikom $u$ vremenu prelaska iz starog u novi milenijum. Razlog za to je bio dvostruk: poslovični ideološki optimizam univerzitetskih prosvetitelja $s$ jedne, te politička i ekonomska dominacija SAD u međunarodnom poretku, s druge strane.

Sve to nije dugo potrajalo - svega par decenija. Istorijski intermezzo u kome su SAD dominirale kao jedina svetska sila (Pax americana: 1989-2008) prestao je da postoji, dok je značaj uloge nacionalnih država iznova porastao. Međunarodni poredak i dalje funkcioniše kao (novi) svetski nered. Da bismo razumeli takvo ishodište i ujedno pojmili političke tendencije koje ono sadrži, morali bi najpre da se osvrnemo na neka iskustva nastanka moderne, tj. nacionalne države.

\section{Istorijska geneza}

Država kao forma i/ili struktura političke zajednice ne postoji oduvek. Štaviše, ona je moderno političko čedo, staro ne više od dva-tri veka. Sve druge, prethodeće političke zajednice, jednostavno nisu bile države: one nisu imale institucije, aktere i legitimacijska načela koja ima moderna, tj. nacionalna država. Za razliku od predmodernih zajednica, država razdvaja moć od metafizike, vlast od boga i pritom preuzima mnoštvo društvenih funkcija koje nikada pre nisu bile u fokusu politike. Tako je (moderna; nacionalna) država postala moćan privredni akter i regulator tržišta, garant pravne i socijalne zaštite, lekar i učitelj društva..., sve to na način koji je 
radikalno razdvaja od ranijih političkih zajednica koje su, bez izuzetka, bile zasnovane na transcendentnim vrednostima, strogim društvenim hijerahijama i nesumnjivom političkom autoritetu.

Predmoderne političke zajednice su se urušavale onda kada više nisu mogle da odgovore na pitanje svoje metafizičke opravdanosti. Moderni kapitalizam i prosvetiteljstvo, zajedno sa globalnim širenjem moći Zapada, učinili su da se svekoliki predmoderni svet uruši pred neodoljivim talasima modernosti koji su od XVI veka nagrizali, da bi u XIX veku konačno potopili gotovo sve ono što je politički postojalo od kada je čovek izašao iz pećina ledenog doba.

Na mesto starih imperija, kraljevstva, kneževina i drugih dinastičkih poredaka, stupile su nacionalne države kao depersonalizovani oblik vladavine zasnovan na kapital-odnosu i samodovoljnom političkom umeću. Kao novi oblik političkog organizovanja država istovremeno afirmiše identitet zajednice ( $u$ čije ime nastupa) i slobodu pojedinca (građana/ državljanina) čiju pravnu jednakost štiti obavezujućim pravnim normama jednakim za sve članove zajednice. Dotadašnja uobičajena legitimacijska načela (sloboda, jednakost, pravda itd.) dobijaju nova značenja zahvaljujući političkim ideologijama koje, opet, ne mogu da otklone napetost između zaštite kolektivnog identiteta i garantovanja ličnih sloboda. Dugotrajuća, ogorčena i krvava borba između političkih ideologija - pseudoreligijskih formi mišljenja/delovanja koje nastoje da formiraju "čiste" i "pravoverne" društvene sisteme u skladu sa svojim temeljnim dogmama, dovela je do zajedničke kompromitacije i opšteg nepoverenja u svaki postojeći politički poredak. Nepoverenje vođeno sumnjom donela je razočaranost, ravnodušnost i najzad ogorčenost sa kojima stiže i novi radikalizam. Jedino (pre)ostaje neutoljiva potreba za bezbednošću, univerzalni transistorijski, transreligijski i transideološki politički zahtev i cilj. Problem je u tome što ta potreba i zahtev nisu nimalo bezazleni, a nisu ni (sasvim) ispražnjeni od posebnih vrednosti, kako bi se to na prvi pogled moglo pomisliti.

Naravno, sve predmoderne političke zajednice, a posebno njihovi čelnici, uvek su imali principijelni zadatak da unapređuju bezbednost i blagostanje svojih podanika (članova zajednica), no tek je moderna država takva nastojanja izmestila iz domena pravičnosti i dobre volje personalnih vođa („,očeva zajednice"). Moderna politika bezbednost i blagostanje zajednice stavlja u ruke bezimenog državnog aparata koji načelno funkcioniše „u ime svih". Državna uprava nije više zavisna od samovolje i odluka vladara, već 
postaje deo ,jjavnog dobra", a njeno vođstvo podložno je redovnim izborima, baš kao i drugi ograni vlasti, posebno oni sudski i zakonodavni. Utoliko upražnjena sveta mesta bogova i monarha sada (u moderni) popunjavaju bezbožni preduzetnici i desakralizovane birokrate. Takav ishod stvari, gledano iz ugla istorije političke misli, niko nije mogao da predvidi, što ne znači da takve tendencije nisu bile uočavane i kao takve tumačene. ${ }^{6}$

Za neke od mislećih to je značilo "skraćivanje političkog", odnosno odricanje od tradicionalne politike i njene vaspitne dimenzije (grč. paideia - moralno oblikovanje slobodnog građanina), dok je za druge sve upućivalo na dramatično proširenje delokruga politike i države koja, za razliku od premodernih vremena, zadire u sve pore društvenog i privatnog života i razvlašćuje druge (para)političke institucije (počev od porodice do staleških, verskih, cehovskih i drugih organizacija). Rečju, moderna država je postala korporacija koja upravlja drugim korporacijama, amalgam društvenih veza i odgovornosti usmeravan od strane legitimnih (ovlašćenih) posvetovljenih vođa. ${ }^{7}$

${ }^{6}$ Makijaveli je to znao, ali nije slavio (već je politički koristio), Hobs se toga pribojavao (ali koristio u argumentaciji), dok je Lok možda sve već dobro razumeo, ali je ćutao jer je, kao i mnogi drugi njegovi prethodnici i poneki savremenici, u svemu tome i sam neposredno učestovao (bio je državni činovnik zadužen za rad britanskih kolonija u Severnoj Americi). Isto tako, liberali Monteskije i Tokvil npr. su o nastupanju i posledicama modernog sveta politike sudili hladno i razborito, dok je „liberalni konzervativac" Berk glasno negodovao, pa opet, ni niko od njih, kao ni većina drugih političkih mislilaca, nije se upuštala $u$ pripovesti o restauraciji srednjovekovne monarhije, niti su sa entuzijazmom govorili o božanskoj misiji kralja da miri zavađene građane i njihove suprotstavljene interese - bar ne onako kako su o tome sa izveštačenom nostalgijom pisali Bonal, De Mestr i njima slični „,reakcionarni” pisci iz doba Restauracije.

${ }^{7}$ Ipak, legitimnost je manjkava i ništavna ako nema legalnosti. Temeljne ideje ili vrednosti legitimnosti ostaju prazne reči ako nema formalnih pravila pomoću kojih se one "otelotvoruju”, tj. realizuju. Moderni politički proces, pogotovo u liberalnim državama, podrazumeva sukcesivno menjanje i potiranje klasifikovanih ciljeva, odnosno legitimizujućih ideja i vrednosti, što dovodi do kontroverzi u pogledu opšteg smera kretanja političke zajednice. Najzad se došlo do toga da ne samo da nije moguće, već je i (navodno) pogrešno, propisivati bilo kakav zajednički cilj ili rukovodeću vrednost koja bi bila obavezujuća u političkoj zajednici, tj. državi. S druge strane, političko delanje zasnovano na nekoj pretpostavljenoj supstancijalnoj vrednosti koja je, navodno, ,imanentna” konkretnoj naciji (narodu), političkim vođama ili već nekoj ekskluzivnoj društvenoj grupi, uskraćuje ili čak potire slobodu izbora, a po definiciji suspenduje obavezujuće procedure. Utoliko je svagda traženo 
U pokušajima da legitimiše nove forme vladanja država je naizmenično igrala ulogu „noćnog čuvara” (minimalistički liberalni koncept) ili pak "Velikog brata" (maksimalistički totalitarni koncept), bila je i „,socijalni inženjer" (komunizam) i "svetovno božanstvo" (fašizam/nacizam), vrednosno neutralni ,,regulator slobodnog tržišta” (liberalizam) i vrednosno zainteresovani "distributer bogatstva" (socijal-demokratija). U poslednjoj velikoj ekonomskoj recesiji (2008) postala je „država-dadilja” za najbogatije slojeve društva, dok u aktuelnoj svetskoj pandemiji (2020) funkcioniše kao dobrovoljni "država-zatvor" za (gotovo) sve građane. Sve te obaveze, odgovornosti i moći državnih upravitelja, mnogo su veće od snage i dometa (premda svakako ne i ambicija) koje su imali ili pokazivali predmoderni vladari i ondašnje političke institucije. Zato su i legitimacijski narativi u modernim, čisto svetovnim političkim zajednicama složeniji no što su to bili oni u predmodernim, sakralnim zajednicama. Za svaku od novih „uloga” i "funkcija" moderne države stvarani su odgovarajući ideološki predlošci pomoću kojih su opravdavani konkretni koncepti političkog ustrojstva.

Praktično, sve ideološke priče koje su do sada ponuđene u tom smislu pojavljivale su se u parovima suprotnosti: počev od onog inicijalnog liberalizam vs. konzervativizam (XVIII-XIX vek), preko temeljenog sukoba: liberalizam vs. socijalizam/komunizam (XX vek), kao i uporednih i znatno pogubnijih alternativa: fašizam/nacizam vs. liberalizam i/ili komunizam (XX vek), sve do savremenih kombinacija, ukrštanja i suprotstavljanja različitih derivata starih ideoloških predložaka koji uspostavljaju nove "mešovite" - postmoderne političke poretke pravljene po sistemu „od svega po malo". Razlog za aktuelnu političku šizofreniju krije se u razočaranju koje je došlo nakon neuspeha svih izvornih ideoloških obećanja i pozivanja na slobodu i jednakost, čast i tradiciju, solidarnost i napredak, snagu i moć rase, nacije, klase ili elite, kao i dokazane nesposobnosti da se zaista reguliše slobodna privreda, uredi javna sfera i stvore uslovi za bezbedan i ujedno slobodan i/ili dostojanstven život.

,jedinstvo" unutar države više predmet proklamacija i očekivanja, obaveznog nadgledanja i čestog kažnjavanja, a mnogo manje ili nikako afirmacija jednakosti i slobode, uključujući i nagrađivanje. Legitimnost se nadmeće sa legalnošću, norma sa istinom i vrednostima. Samim tim ostaje nedohvatna politička stabilnost, sa njom i svaka politička predvidljivost. 
Ideološka obećanja i institucionalna rešenja za slobodu i bezbednost, dostojanstvo i sigurnost, imaju svoju dugu, viševekovnu tradiciju: počev od rane modernosti (stvaranje regionalnog, delimično liberalnog privrednog sistema unutar velikih sila Zapada, XVI-XVII vek), preko kolonijalnog pustošenja i izrabljivanja ostatka sveta (XVIII-XX vek), sve do aktuelnog obrta i novih relacija na globalnoj osi Zapad - Istok. Svaki put je akcentovanje ili apsolutizacija jedne vrednosti izazivalo potiskivanje ili čak zatiranje druge. Onako kako je privredni liberalizam prelazio u svet politike i političkog liberalizma, tako su i ideje demokratske političke jednakosti dobijale svoju socijalnu dimenziju koja je afirmisala komunističku ideologiju.

Komunizam je obećavao prevazilaženje protivrečja između nacionalnih ekonomija i svetske privrede, socijalne bede i industrijskog razvoja, političkih prava (jednakost pred zakonom; politička egalitarnost) i novih društvenih nepravdi (socijalna raslojavanja; ekonomska nejednakost). Kada je „lanac imperijalizma kao poslednjeg stadijuma kapitalizma” (Lenjin) pukao tamo gde je $\mathrm{u}$ tom trenutku bio možda najtanji - $\mathrm{u}$ bogatoj a nerazvijenoj najvećoj zemlji na svetu (Carska Rusija), nastala je fingirana ,zemlja proletera", eksperimentalna komunistička država (SSSR). Iznikla iz Velikog rata, doslovno najvećeg ratnog sukoba $u$ istoriji (do tada), ona je imala ambiciju da postane stožer "svetske proleterske revolucije" koji bi bio u stanju da prevlada ekonomsku, političku i etičku ograničnost kapitalizma kao svetske privrede. To je, bar $\mathrm{u}$ teoriji, značilo i prevladavanje nacionalnih država i stvaranje uistinu novog, do tada nikada institucionalno postojećeg međunarodnog (naddržavnog) poretka.

Međutim, uprkos očekivanjima da će prva proleterska država brzo postati deo internacionalnog sveta ,,slobodnog rada", Sovjetski Savez se po logici real-politike i odnosa moći, pretvorio u državu poput svih drugih nacionalnih država i kao takav nastavio je da traje tokom većeg dela XX veka. ${ }^{8}$ Zato i ne čudi što će se svi potonji politički pokušaji izmirenja ",sveta

\footnotetext{
${ }^{8}$ Ipak, postojala je i izvesna razlika koja se sastojala u tome što je nacionalni identitet (inače svuda na Zapadu zasnovan na nekom etničkom, jezičkom ili kulturalnom osnovu) u slučaju SSSR-a dobio svoju ,„čistiju” ideološku potku. Naime, nekadašnji građani i/ili podanici Carske Rusije, postali su „Sovjeti”, državljani SSSR-a, tj. građani čije je etničko ili nacionalno poreklo bilo potčinjeno njihovom ideološkom komunističkom, dakle nadnacionalnom statusu. Tako je SSSR na određeni
} 
rada i sveta kapitala", koji povezuju tako različite političke poretke kao što su komunističke države na Dalekom istoku nastale nakon Drugog svetskog rata (Kina, Vijetnam, Koreja itd.) i evropske socijaldemokratske „države blagostanja” (Francuska, Zapadna Nemačka, Švedska itd.), po pravilu odigravati unutar nacionalnih država. To je bio i ostao jedini stvarni politički okvir u kome je moguće realizovati legitimitet i svrhu poretka. ${ }^{9}$

Zbog toga su doslovno sve nacionalne države, pogotovo one najmoćnije (uz razumljivi, ali samo relativni izuzetak SAD), ${ }^{10}$ nastojale, a i još uvek to čine, da vlastiti legitimitet spoje sa "svojom" stvarnom ili izmišljenom prošlošću, odnosno etničkim identitetom većinskog naroda ili vladajuće dinastije na datom području - teritoriji. Potraga za kontinuitetom političke zajednice, očitovana u nalaženju dubokih (,,što dubljih") istorijskih korena konkretne države, predstavlja izraz potrebe koju zajednički dele vlast i stanovništvo/građani. Najzad, nacionalna država već samim svojim postojanjem upućuje na izvesne „istorijske ciljeve” koji nadilaze neposrednu

paradoksalan način baštinio i nastavljao tradiciju ruske monarhije koja je svoje dinastičko poreklo i vladavinu smatrala primarnim određenjem u odnosu na versko, jezičko ili neko drugo poreklo svojih podanika. U tom smislu je politička legitimacija sovjetske države, oličena u komunističkom - nadnacionalnom identitetu njenih građana, stajala izvan, preciznije - ispod standarda liberalnih nacionalnih država koje su se temeljile na individualnim političkim pravima svojih građana/državljana, što je obično podrazumevalo, ali nije i potenciralo njihova kolektivna (verska, jezička, kulturna) prava.

${ }^{9}$ Ideja internacionalizma biće preneta u svet real-politike nacionalnih država, sve da bi kasnije doživala i svoje perverzno izdanje u vidu neoliberalističkog „novog svetskog poretka” i pratećih vojnih „humanitarnih intervencija” za sve one koje odbijaju ili ne mogu da se u njega uklope.

${ }^{10}$ Za razliku od drugih modernih ,,velikih sila” (evropskih i azijskih), koje su sa više ili manje opravdanosti mogle da se pozivaju na svoju ",slavnu prošlost” ili „,velike pretke", SAD su nastale na zemlji ili prostoru koji, takoreći, nema svoje istorijsko poreklo, niti je na njega polagano pravo vlasništva od strane „civilizovanih naroda" (da upotrebimo tu tako rado i često korišćenu formulacija evropskih kolonijalnih sila). Međutim, već od druge polovine XX veka, a danas posebno, upravo se u slavnoj istoriji "herojskih pionira” (prvih naseljenika), borbe za samostalnost u odnosu na ondašnje evropske sile („Američka revolicija”), a posebno u građanskom ratu (navodna „,borba protiv ropstva") i naseljavanju Divljeg zapada (ekspanzija "od jednog do drugog okeana"), pronalaze osnove za američki nacionalni identitet koji bi trebao da (p)ostane temelj američke budućnosti i uzor za svakodnevne moralne orijentire za njene građane - nezavisno od njihovog pripadanja posebnim konfesijama i nacijama. 
rutinu političke i svake druge svakodnevnice, njene stvarne ili izmišljene nepravde, društvenu (ne)jednakost i uvek postojeću nesigurnost u odnosu na druge. Otuda potraga za istorijskim korenima nije samo pokazatelj manipulativnih (ne)sposobnosti aktuelne vlasti unutar dotične države, većje i izraz autenične potrebe za smislom i svrhom koji unose red i spokojstvo $u$ haos svakodnevnog preživljavanja. $U$ tom duhu sagledan, nacionalni identitet nije samo „relikt prošlosti” ili neki „zaostatak" istorije zagledane u vrednosti ograničenih (etničkih, plemenskih ili dinastičkiih) društvenih grupa, već je i svrsishodan i legitiman politički konstrukt koji obezbeđuje osećaj pripadnosti (pa tako i važnosti) za svakog pojedinačnog građanina, i čemu pruža i objektivan okvir za efikasnu realizaciju političkih težnji i potreba.

Zahvaljujući liberalnim procesima u politici, privredi i kulturi, koji su istrgli individuume iz klasičnih oblika društvenosti (porodica, lokalna kultura i zajednica), moderni građani u naciji i „njenoj” državi nalaze poslednje utočište za društveni identitet i solidarnost. Učešće u nacionalnom životu prevazilazi ograničenost individualne egzistencije. Na tom osnovu izgrađuje se lojalnost političkoj zajednici, tj. državi koja tako nešto svakako ne bi mogla da očekuje u svojoj ogoljenoj formi obezličenog birokratskog aparata sa monopolom vlasti u kapitalističkoj privredi i dramatičnom socijalnom raslojavanju.

Pored obavezne pravne i fizičke bezbednosti, moderna, dakle nacionalna država, svojim državljanima (građanima) mora da pruži (premda retko to uspeva) i neku višu svrhu/smisao sazdanu u vidu moralne odgovornosti pojedinaca spram zajedničkog istorijskog nasleđa, kolektivnog dostojanstva i budućnosti. Naravno, sve su to nasleđeni, tradiconalni politički zahtevi iz predmodernih vremena, s tim da ih delom možemo razumeti i kao sasvim nove - moderne zahteve koji ranije nisu bili toliko eksplicitni jer je postojala zajednička "slika sveta" i opšteprihvaćene regulatorne vrednosti unutar lokalne kulture i/ili civilizacije.

Država mora da čuva (brani, obezbeđuje) fizičku i pravnu bezbednost, ali isto tako delom i onu "duhovnu" kolektivnu bezbednost. Zato je moderna (nacionalna) država, često neopravdano - što ne znači i nepotrebno - tradiranim uslugama bezbednosti dodavala i nove samopreuzete obaveze ili ,zadatke" koji imaju svoju praktičnu i simboličku dimenziju. U prvom slučaju reč je o nizu različitih načina zaštite od životnih rizika (briga o radu, zdravlju, starosti itd.), dok je u drugom reč o formiranju svesti o zajedničkom dobru u vidu nacionalnog identiteta, koje bi trebalo 
da podrazumeva istovremeno racionalno samopoštovanje (svest o sebi) i racionalnu svest o pravima i interesima drugih država i nacija. Za te i takve potrebe (samo)spoznaje, nužno je bilo i ostalo poznavati i „negovati” zajedničku (nacionalnu) istoriju, sve uz sticanje znanja o tokovima svetske istorije. Ipak, nužno, primat uvek ima sopstvena nacionalna istorija. Sticanje i održavanje znanja o zajedničkoj prošlosti zalog je za racionalno vođenje politike u sadašnjosti i uslov zajedničke (nacionalne) budućnosti. Nažalost, ali i po pravilu, sve to je često znalo ići u pravcu prostog izmišljanja nacionalne istorije (pogotovo tamo gde nacije, odnosno države nikada nije ni bilo) i stvaranja lažne slike o prošlosti koja je stvarana radi „rešavanja” problema u sadašnjosti. U tom slučaju problemi su se samo gomilali a rešenja su izostajala i ostavljana za neka „,bolja vremena”.

Nezavisno od svega toga, pa čak i uprkos nepobitnoj činjenici da je moderna politika „,raskrstila" sa etikom (preciznije: sa religijom/verom), moguće je tvrditi da koncept nacionalne države imanentno sadrži zahtev za novom vrstom veze između politike i etike, tj. za uspostavljenjem novog jedinstva između vlasti i morala, načina vladanja i njegovog opravdanja (legitimacije). Ako bi se svela samo na animalnu borbu za vlast, politika bi izgubila dostojanstvo, pa čak i smisao svog postojanja. Činjenica da ,jači tlači”, ne bi smela da bude i ,poslednja istina" u refleksiji ljudskih odnosa. Međutim, veliko je pitanje da li do neke nove sinteze politike i morala zaista i može doći, pogotovo ako imamo u vidu ciljeve i strukturu moderne privrede i kontinuiranu krizu identiteta samog koncepta moderne države. U svakom slučaju izvesno je da država, kao trenutno univerzalna forma funkcionisanja političke zajednice, nije i ne može biti poslednja reč politike i političkog. Kao što današnji oblik i refleksija države nisu identični onima iz XIX ili XX veka, tako isto ni budući izgled i način funkcionisanja države verovatno neće odgovarati ovom aktuelnom momentu. To ni u kom slučaju ne znači da države neće biti. Prirodno je očekivati da će se ona (država) vremenom menjati, ali kako i u kom pravcu o tome možemo samo da nagađamo. Između nagađanja i sanjarenja gotovo da nema razlike.

\section{Ideološke metamorfoze}

Lucidini analitičar modernog kapitalizma i gorljivi komunistički revolucionar Karl Marks je mislio da će moderna, tj. nacionalna ili „,buržoaska država” iz njegovog vremena (XIX vek), svagda slediti logiku 
razvoja kapital-odnosa (akumulacija, eksploatacija, profit), te da će to imati za posledicu revolucionarno nezadovoljstvo i društvene promene koje će učiniti da takva država postepeno nestaje sve dok na njeno mesto ne stupi „,slobodna zajednica udruženih proizvođača".

Prema Marksovim očekivanjima, takva istorijski potpuno nova transkapitalistička i transnacionalna politička zajednica, bila bi rezultat političke aktivnosti novog ,,istorijskog subjekta" - svetskog proletarijata. U modernom dobu on je potlačena klasa koja raspolaže samo i jedino svojom radnom snagom. Međutim, sledeći logiku svoje „emancipatorske istorijske uloge", kroz upornu političku i privrednu borbu, proletarijat će uspeti da kontroliše tokove proizvodnje, rada i kapitala i tako će najzad „razotuđiti čoveka”, što će biti vraćanje njegovoj „,rodnoj suštini”, odnosno ",slobodnoj stvaralačkoj praksi”. To su bili fragmentarni uvidi „ranog Marksa” koji su poslužili potonjoj komunističkoj ortodoksiji da od utopijskih slika konstruiše „istorijske zakone” razvoja društva (u načelu) i političke dogme zasebne totalitarne države (u pojedinostima).

Ukidanje „eksploatacije čoveka od strane drugog čoveka” Marks je vezivao za sferu proizvodnje, ali isto tako i za njeno naličje ili posledicu svet politike, kulture, ideologije, dakle - državu. Istorija je pokazala da Marksova teorija promašuje u pogledu budućnosti "emancipacije rada" i njegovih društvenih i političkih nosioca (proleteri, komunistička partija, diktatura proletarijata i sl.), ali zato ostaje aktuelna za razumevanje kapitalodnosa, ključne proizvodne matrice modernosti i njene tendencije da stvara (globalne) monopole uz stalno povećavanje socijalnih razlika i animoziteta između nosioca moći i onih koji moć samo trpe, tj. podnose. Istorijsko trajanje kapitalizma je pokazalo da politika (kao deo "društvene nadgradnje”) ne samo da nije prosti pratilac ekonomije („društvene baze”), već ima autonomiju koja je u stanju da postavlja smernice privredi - uprkos logici ponude i potražnje, "zdravog" i bilo kog drugog razuma. Dotična "nadgradnja”, dakle, može i hoće da postane „baza”. Takve ambicije mogu da budu razumne ili nasilne, sve zavisi od konkretnih oklonosti, aktera i političke tradicije iz koje dolaze.

Premda često izgleda suprotno, politika nikada nije iracionalna delatnost, naprotiv, uvek je posvećena istom cilju: brzom i efikasnom putu da se dođe do vlasti. Politika postaje iracionalna tek $u$ fazi održavanja vlasti - tu su i najluđa sredstva "dozvoljena”, samo ako mogu da produže vlast makar samo za još „ovaj put” i za ,još jedan dan više”. Utoliko, ne da nije 
moguće predvideti sudbinu moderne države, već je takav naum zaludan već po definiciji. Naravno, Marks i njegovi sledbenici nisu mislili tako, ali isto to važi i za njihove liberalne ili fašističke rivale. Svejedno je odakle dolaze ideološke parole i njihovi tvorci - oni uvek obećavaju određenu izvesnost jer navodno "znaju budućnost”, tj. imaju pouzdan uvid u istorijske zakone. Podsetimo se zato ukratko glavnih ideoloških „predviđanja” i očekivanja po pitanju dalje sudbine države.

Marks je u lakonskoj sintagmi „diktatura proletarijata” video prelaznu formu od čvrste revolucionarne vlasti proletera ka konačnom nestajanju ili samoukidanju nacionalne države. Bila je to prigodna polemička konstrukcija („Kritika Gotskog programa”) koja se nigde više nije koristila niti teorijski razvijala. Njegovi potonji, sasvim neočekivani komunistički naslednici u liku ruskih boljševika, od te improvizovane političke sintagme napravili su dogmu „države proletarijata” koja svojom „,revolucionarnom delatnošću” radikalnom voljom i radnim elanom priprema „,svetsku revoluciju”. Rečena koncepcija je imala svoju prevashodno lokalnu real-političku dimenziju (srušiti monarhiju u Rusiji i stvoriti novu vlast $u$ njoj), ali i globalnu utopističku „viziju” (proširiti komunističku revoluciju na ceo svet). ${ }^{11}$

Ideologija diktature proletarijata kao „privremenog” revolucionarnog nasilja, nužno se u društvenoj stvarnosti pretočila, a za trockiste i druge ultraleve marksiste - „izvitoperila” u neku vrstu neoklasične oligarhije: umesto nekadašnje aristokratske i potonje plutokratske (kapitalističke) vlasti i privilegovanih elita po poreklu ili bogatstvu, nastala je komunistička vladavina i nove privilegovane elite utemeljene na političkom monopolu. Komunizam se utoliko svodio na aktivnost jedne političke organizacije (komunističke partije), koja upravlja celokupnim političkim, privrednim i kulturnim životom države. Po prirodi stvari, svaki dalji korak rečene dikatature proletarijata, tj. revolucionarne partije, predstavljao je dalje sužavanje svekolike političke i društvene moći na partijsko rukovodstvo i najzad na njihovog vođu. Simptomatično je da se ista stvar dogodila i sa potonjim glavnim komunističkim protivnikom - fašizmom/nacizmom.

${ }^{11}$ Prva, real-politička dimenzija iznedrila je "staljinizam”, okrutni, ali efikasni sistem vlasti nazvan po svom tvorcu, zapravo spretnom političkom improvizatoru Staljinu, dok je utopijska dimenzija - "trockizam”, ništa manje okrutna i nasilna, ali intelektualno „prihvatliivija” za mondijalističke aktiviste, dobila naziv po drugom revolucionarnom vođi boljševičke strahovlade. 
Razlika je $u$ tome što je fašizam/nacizam otvoreno propagirao i temeljio svoju moć na tzv. rasnim ili pseudoistorijskim osnovama, dok je komunizam (baš kao liberalizam $u$ isto vreme) vlastito postojanje opravdavao univerzalističkim parolama koje su propagirale transdržavne ciljeve.

Marksova kritika desne strane političkog spektra (monarhisti, nacionalkonzervativci, nacional-šovinisti $\mathrm{i}$ dr.) funkcionisala je na tragu revolucionarnih transnacionalnih zamisli i nije se previše osvrtala na revolucionarno levičarenje koje je bilo poznato još od ranih dana Francuske revolucije (jakobinci i njihov "revolucionarni teror"). Zato je strah od "diktature proletarijata", uz podrazumevajuću podršku vlasnika kapitala, iskorišćen da se kritika modernog liberalizma, kao noseće forme moderne (nacionalne) države, formira i na suprotnom delu političkog spektra konzervativnoj i šovinističkoj desnici. Na tom osnovu ustoličio se se "desni totalitarizam", koji, za razliku od onog "levog", nije računao na privremenu diktaturu, već na večnu vlast. ${ }^{12}$ Štaviše, nasuprot "diktature proletarijata", koja već sama po sebi sugeriše ili upućuje na neko ograničeno vreme trajanja, fašizam/nacizam je više nalikovao na klasičnu tiraniju (zaodenutu modernim ruhom): „duče", odnosno "firer" bili su izvor i utoka vlasti, dok je krupan kapital (takoreći ,industrijsko plemstvo") funkcionisao kao neka vrsta korisnog posrednika između idealizovanog vođe i naroda $(\mathrm{u}$ nemačkom slučaju: „germanske rase”).

Obe vrste predimenzioniranja, štaviše - apsolutizovanja državne moći: "levi" i "desni" totalitarizam (u sociologiji i politikologiji je dugo bio u upotrebi nešto neutralniji pojam "etatizam"), proizvele su dramatične istorijske posledice, koje opet, nisu istorijski unikatne: velike nepravde $u$ ime „velikih ideja”, sveti ratovi i pokolji - imanentni su deo mračnog nasleđa čovečanstva. Istorijske razlike između antičkih despotija i modernih diktatura uglavnom se odnose na kvantitativne, a ne kvalitativne momente. ${ }^{13}$ Isto tako, istorijska je činjenica da oba ekstremna pristupa državi (njeno navodno negiranje, odnosno apsolutizovanje), predstavljaju reakciju

${ }^{12}$ Takva je bar bila zvanična ideologija italijanskog fašizma i nemačkog nacizma koji su govorili o nastajanju ,hiljadugodišnjeg carstva” i koji, za razliku od zvaničnog komunizma, ni na koji način nisu računali sa vlastitim samoukidanjem. Povrh toga, mnoštvo onovremenih (uzmeđu dva svetska rata ) i potonjih ,desničarskih režima" (posle II svetskog rata), posebno u Južnoj Americi, Aziji i Africi, oslanjali su se na ideoligiju čiste vojne moći i nisu imali milenijarske ambicije.

${ }^{13}$ Misli se na broj žrtava i ratnu tehniku. 
ili odgovor na status države u teoriji i praksi liberalizma - idejnom i iskustvenom osnovu svekolikog modernog sveta.

Razvijajući se na istorijskim osnovama tzv. zapadne, nadasve anglosaksonske političke (pravne i običajne) kulture s jedne, odnosno na privrednom i kulturalnom modernizmu mediteranskih gradova (Firenca i Venecija, pre svih) s druge strane, liberalizam je stvarao društvo u kome je nesputana privatna inicijativa podržana silom centralizovane vlasti postajala uslov razvoja i smisla zajednice. Vlast je osiguravala bezbednost kapitalu, dok je ovaj zauzvrat obezbeđivao konstituisanje političke zajednice (sa ili bez monarha) koja je vremenom i sama postajala preduzetnik i učesnik u kapital-odnosu. Tako je promovisan i glavni socijalni konstrukt i ujedno ključni simbol liberalizma - Novi svet i/ili Amerika (SAD).

U ideološkoj ravni, Sjedinjene Države su od svog osnivanja, odnosno sticanja nezavisnosti, kao glavni legitimacijski motiv isticale obezbeđivanje slobode $i$,,šansi za sreću" svih građana. To je sažeti sadržaj onoga što čini liberalni koncept „minimalne države”. Sve preko ili izvan pružanja bezbednosti za život i svojinu, smatralo se ne samo suvišnim, već i direktno štetnim za samu svrhu države koja treba da obezbedi političku autonomiju svim svojim građanima (uključujući tu i slobodu odlučivanja). Osnovni zadatak države je da obezbedi jednakost svih građana pred zakonom, tj. ravnopravnu poziciju pred izgledima za kažnjavanje ili nagrađivanje), fizičku bezbednost i bezbednost svojine (uključujući tu i sankcionisanje zloupotrebe zakona pri različitim transakcijama između ovlašćenih ličnosti). Sve što je izvan toga - posao, zdravlje, obrazovanje, vera, moralna ili politička uverenja - mora biti prepušteno slobodnoj volji i ličnim sposobnostima građana/državljana SAD.

Drugim rečima, sve ono što spada u domen socijalnih ili ekonomskih prava, a što je danas opšte mesto političkog ustrojstva države (npr. određivanje dužine plaćenog radnog vremena i eventualnog odsustvovanja sa posla, penziono osiguranje, minimalna zdravstvena zaštita, obavezno osnovno obrazovanje itd.) u ranom devetnaestovekovnom, ali isto tako i u razvijenom dvadesetovekovnom liberalizmu, bilo je tretirano isključivo kao domen privatne inicijative, ličnog humanizma ili milosrđa (danas - "filantropija"). U tom vidokrugu promišljanja, država je dužna da obezbedi slobodu poslovanja, tj. da ne ograničava privatnu inicijativu i da ne nameće prevelike poreze. Jedino što ona neizostavno mora da čini jeste da finansira i organizuje rad policije i 
vojske koji štite poredak iznutra i spolja. Ništa više, ali i ništa manje od toga! Utoliko liberalizam, u svim svojim "neo", ,"socijal”, ,hrišćanskim”, "demokratskim" i drugim varijantama, ima neizbežnu posledicu: otvorenu i nemilosrdnu borbu za opstanak na svim mogućim vrstama ",tržišta" - od privrednog, preko političkog do moralnog (verskog), etičkog ili estetičkog. To bi bila neizbežna cena slobode ili autonomije pojedinca!

Tako utemeljen liberalizam iznedrio je velike pomake u slobodnom i kreativnom oblikovanju ljudskih potencijala, ali je isto tako proizveo i mnoge pogubne socijalne i političke učinke: od istorijski nezabeleženog socijalnog raslojavanja do analognog monopolizovanja moći od strane „najuspešnijih“. Tako se stvorilo društvo nove aristokratije i stare sirotinje. Razlika u odnosu na klasične aristokratske sisteme je $\mathrm{u}$ tome što su današnje „,vođe" i „,pobednici" (oni koji su na vrhu društvene piramide), navodno izdanak nove vrste "prirodne aristokratije” (T. Džeferson) - preduzimljivi, marljivi i razumni ljudi, dok su svi drugi (poraženi gubitnici), naprosto „,neuspešni” ljudi jer nisu spremni na kontinuiran kreativni rad, stalni rizik i pokretljivost. Problem je bio i ostao da se dati način razmišljanja uklopi u proklamovani ideološki ideal liberalizma: jednake šanse za sve i pravna jednakost svih!

Kako god, liberalizam je bio i ostao izvor kontinurane krize modernog doba koja se manifestuje $u$ bezbroj različitih dimenzija društvenog i individualnog života. Odgovori na tu ,,sistemsku krizu" modernosti bili su narečeni (,,levi" i „,desni”) totalitarni režimi koji su nastajali na realnim egzistencijalnim osnovama, poput straha od nemaštine, zapostavljenosti i zaboravljenosti, a da bi na tom tragu stvarali svoje političke i ideološke sadržaje koji su pružali samo privide sigurnosti, solidarnosti i nade u bolje sutra. Komunistička revolucija u Rusiji (1917), fašistička revolucija u Italiji (1923) i nacistički državni (polu)udar u Nemačkoj (1933), bili su paradigmatični modernistički totalitarni odgovori na preteći i stvarni nihilizam vladajućeg liberalizma. Veoma brzo se pokazalo da su takve nade i delovanje ne samo jalovi, već i kranje pogubni, te da je obećana sigurnost zapravo siguran put $\mathrm{u}$ ropstvo, a veštačka solidarnost samo izgovor za uspostavljanje starih privilegija od strane novih oligarhija.

Vojni poraz militantnog fašizma/nacizma koga su zajedničkim snagama ostvarile snage neočekivanih saveznika - zapadni liberalizam (Velika Britanija iSAD) i istočni komunizam (SSSR), doveo je do novog sučeljavanja te dve osnovne ideološke paradigme modernosti. Zahvaljujući 
neočekivanom istorijskom paradoksu (mada možda samo privremenom!): razvoj vojne tehnologije, tj. atomskog naoružanja zamrzava mogućnost otvorenog frontalnog rata između velikih sila, vreme tokom druge polovine $X X$ veka proteklo je u tzv. Hladnom ratu, ne i klasičnom modernom vojnom sukobu sa milionskim žrtvama. Hladni rat je podrazumevao stalno ideološko takmičenje i oružano sukobljavanje velikih sila ali samo preko trećih lica država u razvoju i onih koje su izjedali unutrašnji sukobi, tj. građanski ratovi. Pobednik $\mathrm{u}$ tom vatrenom ideološkom, a uzdržanom i relativno kontrolisanom oružanom sukobu bile su SAD i njeni zapadnoevropski saveznici. Oni su imali znatno više kapitala, vremena, pa čak i resursa, ako ne i oružja u odnosu na komunistički blok predvođen SSSR-om.

Kada je posle duge i neizvesne borbe, sovjetski komunizam faktički "odustao od trke" i prestao da postoji kao ideološki poredak i vizija, liberalizam je došao u priliku da obznani ideološki ,"kraj istorije”. Međutim, „sistemska kriza” koja je od samog početka činila privredno i političko jezgro liberalizma (i/ili modernog sveta), nije iščezla zajedno sa svojim neprijateljem. Naprotiv, razobručena najnovija verzija (neo)liberalizma u vidu nemuštog parafraziranja izvorno fašističke parole o „novom svetskom poretku", ovaj put predstavljena kao sistem svetskog poretka kojim upravljaju međunarodne institucije predvođene navodno benevolentnom političkom voljom jedine preostale ",super-sile” (SAD), uprkos očekivanjima i čak možda i iskrenim namerama, veoma brzo je dovela svet u zaoštrenije, ako ne i gore stanje nego ono u kome je bilo tokom ideološkog „Hladnog rata". Sada su se uništavajućim klasičnim ratovima (unutrašnji/građanski i međudržavni) i dramatičnoj neravnoteži moći na globalnom planu, pridružile i ekološke nedaće izazvane ljudskom aktivnošću, odnosno pohlepom koja sledi iz nesputane borbe globalnih monopolista na neregulisanom svetskom tržištu. Dodatni dramatični rast socijalnih i/ili političkih razlika između država i unutar njih, kao i stalni porast nezaposlenosti usled brojnih interenih i eksternih razloga (od lokalnih monopola i međunarodne korupcije do razvoja veštačke inteligencije), učinili su da modernu politiku ponovo sagledavamo/razumevamo iz ugla velikih i malih država, moćnih i krhkih političkih zajednica, a ne ideoloških „velikih priča", obećanja i pravdanja, zvali se oni "liberalizam”, ,,socijalizam”, , populizam” ili kako već drugačije.

Zahvaljujući najpre štamparskoj, a odmah zatim i elektronskoj, odnosno digitalnoj tehnologiji, svet je danas postao „manji” i pregledniji, a vreme 
takoreći „zgusnuto", tako da je ono što je svagda bilo na delu - ali sa odloženim dejstvom i zakasnelom refleksijom - međusobna povezanost svake lokalne privrede, kulture i politike sa svetskim trendovima, danas postalo belodano i svima raspoloživo. Postavši medijsko "globalno selo", svet je samo predočio većem broju "korisnika" ono što su vodeći privrednici, političari ili istoričari oduvek znali, samo što nisu imali potrebe, interese ili mogućnosti da saopšte i drugima. Primera radi, još mnogo ranije nego što je to postalo opšte mesto $X X$ veka, dobro se znalo da svaki rat na Bliskom istoku ima direktne posledice po Evropu i Centralnu Aziju, a sledstveno tome i na ostale delove sveta. Međutim, to je dugo vremena bilo najpre "tajno" znanje političkih delatnika i vojnih čelnika, tj. „,ekspertsko znanje", privilegija velikih preduzetnika i državnika na čelu velikih sila. Danas je to opšte mesto neobaveznog ćaskanja u provincijskim kafanama. Isto vredi i za sve druge vrste vesti i njihovu globalnu relevantnost: od "demonstracija kišobrana" u Hong Kongu i protesta ,žutih prsluka” u Parizu, preko napada hladnim oružjem na slučajne prolaznike u Zapadnoj Kini ili Nemačkoj, pucanja na muslimane u džamiji na Novom Zelandu, ideoloških sukoba i rasnih nemira u Iranu ili Americi, do požara u Australiji ili Kaliforniji. O promenama na svetskim berzama i/ili privrednim recesijama da i ne govorimo.

\section{Budućnost bez proricanja}

Futurolozi su verovatno najsporniji predstavnici potrebe za „,naučnom predikcijom" u društvenim naukama. Oni su oduvek postojali, samo što su se ranije zvali vračevi i veštice, magovi i proroci. Kao takvi, najčešće su bili i ostali - prevaranti. Za razliku od njih, futurolozi su u obavezi da isporučuju „čvršće dokaze“ za svoja predviđanja. Stoga moraju da se oslanjaju na "nauku“ - šta god pod tim podrazumevali.

Moderno doba je sa napretkom i hegemonijom „,naučnog pristupa” od novouspostavljenih društvenih nauka očekivalo ne samo da objašnjavaju i tumače, već nadasve da predviđaju društveni razvoj i tokove, posebno ekonomske. Rečeno predviđanje, kao „naučna predikcija”, ima svoju čisto upotrebnu vrednost $\mathrm{i}$ zato je tako popularno i konjukturno u savremenom svetu. U kojoj meri je zaista i „,naučno”, ostaje naizgled neodlučeno, mada je sasvim izvesno da ne može biti egzaktno i pouzdano. Samim tim najčešće ostaje u sferi sanjarenja, sve i kada se naziva „futurologija”. Najčešće je reč 
o prostom priželjkivanju, strahu (distopije) ili nadi (utopije) ili pak naivnom očekivanju da aktuelni društveni i tehnološki trendovi imaju svoj prepoznatljivi ,zacrtani razvoj" (nekada se to zvalo upisanom sudbinom ili usudom) koji se može zdravorazumski pratiti i dokučiti. Preduzetnici na osnovu toga nastoje da zarade, političari da se (možda) pripreme, a ostali da se razonode. ${ }^{14}$

Slično Marksovim očekivanjima, tako je i dobar deo savremenih "futurologa" u likovima pojedinih filozofa, sociologa, pravnika i ponekog političara, donedavno predviđao da će moderna, tj. nacionalna država vremenom sve brže „,nestajati” ili „propadati”, te da će na njeno mesto stupiti, ako ne već "svetska vlada“, a ono sigurno (jer je, navodno, to već uveliko na delu), transdržavni, tj. ,,međunarodni poredak” formiran delovanjem vodećih nacionalnih država, kao i različitih transnacionalnih (međunarodnih) političkih, privrednih, kulturnih, sportskih i drugih sličnih organizacija.

Na tragu takvog razmišljanja i razumevanja moderne političke scene dolazilo se do zaključaka da će "međunarodna zajednica”, otelotvorena u vidu brojnih (ne)formalnih grupa i foruma: od Ujedinjenih nacija i njenih razlčitih agencija i tela (UNICEF, UNHCR...), preko političkih i ekonomskih saveza nacionalnih država (onih "zapadnih": NATO, MMF, Svetska banka, a možda i „istočnih": BRIK i dr.), do manje obavezujućih ,političkih formata" kao što su okupljanja aktuelnih i potencijalno velikih sila (sastanci država koje ulaze u sastav G7 ili G8, možda G20 itd.), postupno obrazovati transnacionalni institucionalni (politički i ekonomski), odnosno vrednosni (moralni i kulturni) poredak, koji će postati obavezujući za sve političke zajednice na planeti.

Korak dalje u tom razumevanju stvari i projektovanju odnosa bilo bi, ako ne već stvaranje svetske države i njene vlade, ono svakako neko konkretnije institucionalizovanje globalnog (svetskog) sistema u kome bi sve političke zajednice delile iste vrednosti i tako bivale podjednako motivisane da ih ostvaruju ili štite. To bi predstavljalo razumno razrešenje suprotnosti između posebnih (nacionalnih) i opštih (međunarodnih) interesa, put ka međunarodnoj stabilnosti od koje bi svi podjednako imali korist - države i narodi, korporacije i radnici, društvene grupe i pojedinci. Ipak, koliko god takva nastojanja bila razumna i potencijalno plemenita,

${ }^{14} \mathrm{U}$ tom smislu vredi čitati i porediti futurološka predviđanja nastala u poslednja pola veka - od Alvina Toflera, preko Žaka Atalija do Noa Havarija ili Martina Risa. 
ona obično samo prikrivaju posebne interese (najjačih), pri čemu je gotovo svejedno da li se radi o „lošim namerama” ili "naivnosti”.

Iskustvo i zdrav razum nam govore da to nije moguće ostvariti, pogotovo ne u svetu nacionalnih država koje sve, bez izuzetka, sa punim opravdanjem, prvo strahuju za svoju bezbednost, a tek potom misle na sve drugo (i druge). Gledano iz tog ugla, svetska država bi mogla da funkcioniše samo kao ideal ili vizija, nipošto ne i kao politička realnost. Kada bi ovo drugo bilo na delu, svet bi bio izložen najvećoj mogućoj tiraniji - svetskoj izvršnoj vlasti bez demokratske (ali i bilo koje druge) kontrole. ${ }^{15}$ Isto tako, istorija poznaje nepregledan niz običajnih, pravnih i političkih institucija koje su se odnosile na regulisanje odnosa između pojedinaca, svakog od njih ponaosob prema političkoj zajednici i najzad zajednica između sebe. Ne postoji nijedan stvarni argument $u$ prilog tezi da bi se svi oni jednog dana mogli (ili trebali) pretočiti u neki jedinstven - uniformni obrazac, tj. zajedničke institucije i obavezujuća pravila jedinstvenog ("svetskog") sistema vrednosti. Najzad, nije realno očekivati da ",bogatstvo u razlikama" proizvodi samo plodove miroljubivosti i saradnje. Milenijumsko iskustvo čovečanstva svedoči upravo suprotno.

\section{Bibliografija}

Blumenberg, Hans, Legitimnost novog veka, Izdavačka kljižarnica Zorana Stojanovića, Sremski Karlovci, Novi Sad, 2004.

Cvetković, Vladimir N., „Filozofsko sabiranje epohe”, u: Moć i mudrost (O političkoj dimenziji filozofije), Službeni list SRJ, Beograd 2001.

Cvetković, Vladimir N., Volja za novo (O genealogiji modernosti), Dereta, Beograd, 2007.

Cvetković, Vladimir N., „,Državna suverenost i/ili nacionalna bezbednost“, $\mathrm{u}$ : Državni poredak - Suverenitet u vremenu globalizacije, SANU, Beograd, 2019.

Ingeborg, Maus, Ljudska prava, demokratija i mir (Perspektive globalne organizacije), Albatros plus, Beograd, 2017.

${ }^{15}$ Vidi Imanuel Kant: „Večni mir” u: Um i sloboda, Beograd 1974. Ono što je Marks bio za doktrinarne komuniste- ideološki vodič i teorijski oslonac - to je Kant za današnje (neo)liberale. Vidi: Ingeborg Maus, Ljudska prava, demokratija i mir (Perspektive globalne organizacije), Albatros plus, Beograd, 2017. 


\section{Vladimir N. CVETKOVIĆ}

\section{NATIONAL STATE: MEANING AND PERSPECTIVES}

Abstract: In the first part of this paper, the author discusses the foundations and evolution of the legitimization principles by which the action and purpose of the modern state are justified. Also, the paper gives an overview of the possible political forms and structural relations through which people strive to establish a successful (efficient) and legitimate (accepted) rule or the social and political order which functions in accordance with its proclaimed principles. In the middle section of the paper, the author shows the gradual appearance of the modern (national) state and critically assesses some theses from the corps of political philosophy, which have served as the justification for the creation of modern states. Many authors have pointed out that the modern state has become a corporation that governs other corporations, as well as an amalgamation of social connections and responsibilities directed by the legitimate (authorized) leaders. Likewise, in its attempts to legitimize new forms of governing, the state has intermittently played the part of the "Night Guardian" (the maximalist liberal concept) or the "Big Brother" (the maximalist totalitarian concept), or the state has also served as a "social engineer" (Communism) and "Earthly Divinity" (Fascism/Nazism), value-neutral "free market regulator" (Liberalism), and morally interested "wealth distributor" (Social-Democracy). Although liberal ideology prevailed following the end of the Cold War, the "systemic crisis" which was from the very beginning the economic and political core of liberalism (and/or modern world), did not fade with its enemy (the Soviet model). Therefore, according to this author, we cannot speak about the end of history as long as the future political and spiritual streams cannot be foreseen with certainty but can only be anticipated. Keywords: legitimacy, state, ideology, political philosophy, history. 